\title{
Use of Bentonite Clay for the Reduction of Cyanide Poisoning after Consumption of Cassava waste water by Wistar Albino Rat
}

\section{*10KOYE, NGOZI FRANCA; ${ }^{2}$ UWHEN, OBRUCHE EDIJALA}

\author{
Department of Biochemistry, University of Port Harcourt, Rivers State, Nigeria \\ Correspondence author email: francaokoye1@yahoo.com
}

\begin{abstract}
The in vivo study of the effect of bentonite on cyanide poisoning and its effect on plasma urea was investigated. A total of 45 wistar albino rats were used. The rats were divided into four groups and a control group. Each group had nine rats including the control. Groups $1,2,3$, and 4 were given a daily dose of $0.4 \mathrm{ml}$ of cassava waste water containing a sub-lethal amount of cyanide $\left(2.16 \times 10^{-3} \mathrm{mg}\right)$. Groups 2,3 , and 4 were counter administered with $0.2 \mathrm{ml}, 0.4 \mathrm{ml}$, and $0.8 \mathrm{ml}$ of $7 \%$ bentonite solution respectively. Administration of bentonite was done simultaneously with the cyanide administration. At the end of each week three animals were sacrificed from each group and the control and their plasma urea level determined. The experiment which lasted for three weeks showed that the sub-lethal amount of cyanide caused a significant increase $(\mathrm{p}>0.05)$ of plasma urea from $0.0300 \pm 0.01 \mathrm{mmol} / \mathrm{L}$ per gram of rats in the control to $0.0375 \pm 0.01 \mathrm{mmol} / \mathrm{L}$ per gram of rats in group 1 which was fed with only cyanide. A counter treatment with bentonite led to significant decrease $(\mathrm{p}>0.05)$ in plasma urea from $0.0413 \pm 0.10 \mathrm{mmol} / \mathrm{L}$ to $0.0249 \pm 0.01 \mathrm{mmol} / \mathrm{L}$ per gram of body weight of the rats. The reduction of plasma urea caused by bentonite was also proportional to the amount of bentonite administered. $0.2 \mathrm{ml}$ and $0.8 \mathrm{ml}$ of $7 \%$ bentonite solution caused a $5.08 \%$ and $39.71 \%$ reduction of plasma urea level respectively. This suggests that bentonite might have some preventive and therapeutic effects on cyanide poisoning. (C) JASEM

http://dx.doi.org/10.4314/jasem.v20i3.1
\end{abstract}

Key words: Bentonite, Calcium, Cyanide, Plasma, Poisoning, Urea

Bentonite clay has a very strong negative ionic charge. This negative ionic charge attracts things that have a positive charge, such as heavy metals, toxins, harmful bacteria, pesticides, and other pathogens. Calcium bentonite clay is highly charged with negative ions and can attract positive ions to it when 'activated'. In its dry form, calcium bentonite clay is inert. When it becomes hydrated, the negative ions are activated and begin their work of attracting free radicals, impurities and other toxins to them. The clumping action of clay makes it bind to heavy metals and pathogens to prevent them from passing through the intestines to the bloodstream. The clay binds with these toxins and then makes an exit via the colon and the kidneys (Craig, 2012). Bentonite clay stems back far in history as a traditional healing method for protecting the body from disease. It has been reported that several traditional cultures living in regions of the Andes, Central Africa and Australia have consumed clays in numerous ways for centuries. Because the clay is readily available and required no modern processing, it has been a popular and costeffective way of "detoxing" the body for quite some time (Gitipour, et al., 1997; Hosterman and Patterson, 1992). Bentonite clay has also been shown to adsorb Volatile Organic Compounds (VOCs), possibly reducing human exposure to these dangerous compounds. (Klein and Barbara, 2007; Günister, et al., 2006; Shaffer et al., 2001; Zaitan, et al., 2000)
Cyanides are salts or $C$-organyl derivatives of hydrogen cyanide that is, any compound that contains the cyano group $(\mathrm{CN})$, and (Mc Naught and Wilkinson, 1997) .They are rare but potentially deadly poison. They work by reversibly binding to the iron III $\left(\mathrm{Fe}^{3+}\right)$ of cytochrome c oxidase thereby disrupting the electron transport chain. This results in the inability of the organism to generate ATP from oxidative phosphorylation. As a result, intracellular oxygen utilization ceases. Cells are then forced into anaerobic metabolism, creating lactic acid and leading to acid-base imbalances and metabolic acidosis. (ATSDR, 1997; Biller, 2007). Cyanide poisoning occurs when a living organism is exposed to a compound that produces cyanide ions $\left(\mathrm{CN}^{-}\right)$ when dissolved in water.

Substances containing cyanide had been used for centuries as poisons, but cyanide itself was first identified in 1782 by the Swedish chemist Scheele. Cyanides are produced by certain bacteria, fungi, and algae and are found in a number of plants. They are found in substantial amounts in certain seeds and fruit stones, e.g. those of apricots, apples, and peaches. Also, they are used in pesticides and fumigants, plastics, electroplating, photographic developing, mining, dye, textile and pharmaceutical industries. In plants, cyanides are usually bound to sugar molecules 
in the form of cyanogenic glycosides. These serves as defence against plant herbivores. Cassava also contains cyanogenic glycosides. (Chikezie, 2013; Vetter, 2000; Jones, 1998; Greenwood and Earnshaw, 1997)

People may be exposed to low levels of cyanides in their daily lives from foods, smoking and other sources. However, lethal exposures to cyanides result only from accidents, suicides or homicides. Inhalation of cyanide gas, especially within an enclosed space, poses a significant health risk. Ingestion of food and beverages containing cyanide can also cause health effects. The severity of health effects experienced depend upon the route and duration of exposure, the dose, and the form of cyanide. (ATSDR, 1997).

Cassava (Manihot esculenta) is an important tropical root crop providing energy to about 500 million people. The presence of the two cyanogenic glycosides, linamarin and lotaustralin, in cassava is a major factor limiting its use as food or feed. Cyanogens in cassava plants are converted to cyanide when raw cassava is eaten or processed. The proper processing of cassava - drying, soaking in water, rinsing or baking - effectively reduces cassava's linamarin content. But shortcut processing which are frequently used during famines, can yield toxic food products.

Chronic, low-level cyanide exposure is associated with the development of goitre and with tropical ataxic neuropathy, a nerve-damaging disorder that renders a person unsteady and uncoordinated. Severe cyanide poisoning, particularly during famines, is associated with outbreaks of a debilitating, irreversible paralytic disorder called Konzo and, in some cases, death. The incidence of Konzo and tropical ataxic neuropathy can be as high as $3 \%$ in some areas. People who get little or no protein in their diets are particularly susceptible to cyanide poisoning, as they lack the proper amino acids necessary to help detoxify the poison. (Bernan 2008; Alonso et al., 2003; Schulz et al., 2003; Hague, 2002; Bender and Bender, 1997). Urea is synthesized in the body of many organisms as part of the urea cycle, either from the oxidation of amino acids or from ammonia. Amino acids from ingested food that are not used for the synthesis of proteins and other biological substances or produced from catabolism of muscle protein are oxidized by the body, yielding urea and carbon dioxide, as an alternative source of energy (Sakam, 1963).

The objective of this work is to study the effect of bentonite in controlling cassava cyanide poisoning by measuring the urea content of Wistar albino rat.

\section{MATERIALS AND METHOD}

Urea kit was obtained from Randox Laboratories, Limited United Kingdom. Other reagents used were of analytical grade and were prepared with distilled water.

A total of forty five male and female wistar albino rats (Ratus rattus) were obtained from the small animal holding unit of the department of Biochemistry, University of Port-Harcourt, Choba Nigeria. The average weight of the rats was $100 \mathrm{~g}$. They were housed in clean metabolic cages which were cleaned of wastes twice daily at 12 hours each of day and night at room temperature.

Sample collection: Calcium bentonite clay was obtained from bentonite deposit at Anambra state in Nigeria.

Cassava (Manihott esculenta) root was bought from the Choba local market, and was identified in the Plant Science and Biotechnology Laboratory of the University of Port Harcourt.

Sample preparation: Fresh cassava tuber was collected and pilled. $15 \mathrm{~g}$ of the pilled cassava was soaked in $200 \mathrm{ml}$ of water for 3 hours.

\section{Determination of cyanide content in the cassava} extract (Kamalu and Oghome, 2012)

$15 \mathrm{~g}$ of sample was measured into $800 \mathrm{ml} \mathrm{kjedahl} \mathrm{flask}$ containing $200 \mathrm{ml}$ distilled water and allowed to stand for 3 hours at $25 \pm 5^{\circ} \mathrm{C}$. Autolysis was carried out with the apparatus connected to a distiller. A $150 \mathrm{ml}$ distillate was collected in $20 \mathrm{ml} 25 \%$ of $\mathrm{NaOH}$ solution and further distilled to $250 \mathrm{ml}$ with distilled water. $100 \mathrm{ml}$ of the distilled distillate was mixed with $8.0 \mathrm{ml}$ of $6 \mathrm{M} \mathrm{NH} \mathrm{NH}_{4} \mathrm{OH}$ and $2.0 \mathrm{ml}$ of $5 \% \mathrm{KI}$ indicator solution and titrated against $0.002 \mathrm{M} \mathrm{AgNO}_{3}$. The end point was indicated with a faint permanent turbidity appearance. The cyanide content $(\mathrm{mg} / 100 \mathrm{~g}$ cassava wet weight) of the sample was evaluated from the expression:

$1.0 \mathrm{ml} 0.02 \mathrm{M} \mathrm{AgNO}_{3} \equiv 1.08 \mathrm{mg} \mathrm{HCN}$

After the test, it was observed that $200 \mathrm{ml}$ of cassava waste water from $15 \mathrm{~g}$ of cassava (with the back pilled off) contains $1.08 \mathrm{mg}$ of hydrogen cyanide $(\mathrm{HCN})$. Ronald (1932) had earlier reported the LD50 of cyanide to Wistar rat and found that the sub-lethal dose of cyanide to Wistar rat is 0.1 to $10 \mathrm{mg} \mathrm{CN} / \mathrm{kg}$ body weight of rat.

$1.4 \mathrm{~g}$ of bentonite was mixed with $20 \mathrm{ml}$ of distilled water to obtain $7 \%$ of bentonite solution.

Urea determination: Urea levels were determined by enzymatic colorimetric endpoint method. The principle of this method is that urea is hydrolysed by urease into ammonia and carbon dioxide. The ammonia generated reacts with alkaline hypochlorite and sodium salicylate in the presence of sodium 
nitroprusside as coupling agent to yield a blue chromophore. The intensity of the colour formed is proportional to the concentration of urea in the sample (Young, 1995; Tietz, 1995).

The reagent kit contained reagent 1: (urease $>500 \mathrm{U} / \mathrm{ml}$ ), stabilizers. Reagent 2/; (buffered chromogen), phosphate buffer (20mmol/1 pH 6.9), EDTA $(2 \mathrm{mmol} / \mathrm{l})$, sodium salycilate $(60 \mathrm{mmol} / \mathrm{l})$, sodium nitroprusside $(3.4 \mathrm{mmo} / \mathrm{l})$. Reagent 3: Alkaline hypochlorite, sodium hypochlorite (10 $\mathrm{mmol} / \mathrm{l}), \mathrm{NaOH}(150 \mathrm{mmol} / \mathrm{l})$, urea standard, urea $(8.3$ $\mathrm{mmol} / \mathrm{l})$. The working reagent was prepared by mixing $1 \mathrm{ml}$ of reagent 1 with $24 \mathrm{ml}$ of reagent 2 . $1.00 \mathrm{ml}$ of the working reagent was mixed with $10 \mu \mathrm{l}$ of the sample. The standard tube contained $1.00 \mathrm{ml}$ of the working reagent and $10 \mu 1$ of the standard. The blank tube had $1.00 \mathrm{ml}$ of working reagent. The mixture was incubated for 5 minutes at $37^{\circ} \mathrm{C}$ and absorbance of sample read against the reagent blank at $600 \mathrm{~nm}$ with Spectronic-20 spectrophotometer.

Calculations: Concentration of Sample $=\Delta \mathrm{A}_{\text {sample }}$

$\mathrm{x} \mathrm{C}_{\text {standard }}=\mathrm{mg} / \mathrm{dL}$ urea $\times 0.1665=\mathrm{mmol} / \mathrm{l}$

$\Delta \mathrm{A}_{\text {standard}}$. Normal values: $2.5-6.6 \mathrm{mmol} / 1$.

Table 1: Administration of cyanide and bentonite to the wistar rats

\begin{tabular}{llllll} 
& ADMINISTRATION & ANIMALS SACRIFICED AT THE \\
\hline & Cassava waste water & Bentonite(in solution) & 7th day & 14th day & 21 st day \\
& administered & administered & & 3 & 3 \\
Group 1 & $0.4 \mathrm{ml}$ & Nil & 3 & 3 & 3 \\
Group 2 & $0.4 \mathrm{ml}$ & $0.2 \mathrm{ml}$ & 3 & 3 & 3 \\
Group 3 & $0.4 \mathrm{ml}$ & $0.4 \mathrm{ml}$ & 3 & 3 & 3 \\
Group 4 & $0.4 \mathrm{ml}$ & $0.8 \mathrm{ml}$ & 3 & 3 & 3 \\
Control & Nil & Nil & 3 & 3 \\
\hline
\end{tabular}

Note: $0.4 \mathrm{ml}$ of cassava waste water contains $2.16 \times 10^{-3} \mathrm{mg}$ of $\mathrm{HCN}$

Statistical analysis: Data analysis was performed using the Statistical package for the Social Sciences software (SPSS, version 11.0). Data is displayed in mean \pm SD. The statistical method of one way analysis of variance (ANOVA) was used to compare the mean values obtained among different groups. Differences were considered significant whenever the $\mathrm{p}$-value is $\mathrm{P}<0.05$.

\section{RESULTS AND DISCUSSION}

The effects of bentonite on cyanide administration on plasma urea level of rats at constant concentration over time are shown in Table 2. Exposure to cyanide alone without treatment with bentonite (group I) caused a significant $(\mathrm{P}<0.05)$ increased in the plasma urea level as compared with the control. Moreover bentonite administration in groups II, III, and IV caused a reduction of the increased plasma urea

Table 2: Effect of Bentonite on Plasma Urea Level of Cyanide Fed Wistar Albino Rat. GROUPS Plasma urea level/gram body weight ( $\mathrm{mmol} / \mathrm{L})$

$\begin{array}{lccc} & \text { WEEK } 1 & \text { WEEK } 2 & \text { WEEK } 3 \\ \text { I } & 0.0375 \pm 0.01 & 0.0375 \pm 0.01 & 0.0413 \pm 0.10^{*} \\ \text { II } & 0.0300 \pm 0.01 & 0.0327 \pm 0.01 & 0.0392 \pm 0.10^{*} \\ \text { III } & 0.0235 \pm 0.01 & 0.0310 \pm 0.02^{*} & 0.0286 \pm 0.01 \\ \text { IV } & 0.0233 \pm 0.01 & 0.0290 \pm 0.02^{*} & 0.0249 \pm 0.01 \\ \text { V(control) } & 0.0300 \pm 0.01 & 0.0300 \pm 0.01 & 0.0300 \pm 0.01\end{array}$

The results are expressed as mean \pm standard deviation. Values with superscript $\left.{ }^{*}\right)$ show a mean difference that is significant at $\mathrm{P} \geq 0.05$.

In the present study, plasma urea level was found to be increased following cyanide exposure. Table 2 showed the mean results \pm SD of effect of bentonite on plasma urea level of cyanide fed Wistar albino rats. The study showed that the bentonite decreased the effect of the cyanide poisoning in a concentration dependent manner. The highest decrease of $0.0249 \pm$ 0.01 vs $0.0413 \pm 0.10 \mathrm{mmol} / \mathrm{l}$ was obtained with 0.8 $\mathrm{ml}$ of bentonite solution. The lowest decrease of $0.0300 \pm 0.01$ vs $0.0413 \pm 0.10 \mathrm{mmol} / \mathrm{l}(\mathrm{p}>0.05)$ was obtained with $0.2 \mathrm{ml}$ of bentonite solution. Significant increase in plasma urea level has been reported in agreement with this finding in rats and rabbits as well as in pigs following cyanide exposure (Manzano et al., 2007). The results also show that continuing administration of constant cyanide dosage without treatment caused increase in serum level as the week goes by. Cyanide poisoning could have occurred by the alteration of the last enzyme in the electron transport chain the cytochrome c oxidase. It receives an electron from each of four cytochrome c, and transfers them to an oxygen molecule to form two molecules of water (Heydel et al., 2008; Shragg et al., 1982). This process eventually creates a transmembrane difference of proton electrochemical potential that the ATP synthase then uses to synthesize ATP. The cyanide ion $\left(\mathrm{CN}^{-}\right)$competitively binds to cytochrome c oxidase (Alonso, et al., 2003) inhibiting the action of the enzyme. The electron transport chain is therefore halted before its complete 
cycle leading to chemical asphyxiation of cells. Although cyanide poisoning can be difficult to detect, its effect are similar to those of suffocation. Cyanides make it impossible for cell to use oxygen. Some of the effects include, general weakness, coma, seizures, apnea, cardiac arrest, giddiness, headaches, vertigo, confusion, difficulty in breathing. Other effects include mild liver and kidney damages (Sousa et al., 2002).

The United States standard cyanide antidote kit first uses a small inhaled dose of amyl nitrite, followed by intravenous sodium nitrite, followed by intravenous sodium thiosulfate. Hydroxocobalamin is newly approved in the US and is available in Cyanokit antidote kits. Sulfanegen TEA, which could be delivered to the body through an intra-muscular (IM) injection, detoxifies cyanide and converts the cyanide into thiocyanate, a less toxic substance. Alternative methods of treating cyanide intoxication are used in other countries. Cyanide is detoxified in the body, by the enzyme rhodanese in the presence of sulphurcontaining amino acids, to produce thiocyanate (Cipollone, 2008). This reaction takes place in two steps. In the first step, thiosulfate reacts with the thiol group on cysteine- 247 to form a persulfide 2 . In the second step, the disulfide reacts with cyanide to produce thiocyanate, itself being converted back into the "normal" thiol. The use of thiosulfate solution as an antidote for cyanide poisoning is based on the activation of this enzymatic cycle.

Goitre and cretinism due to iodine deficiency can be exacerbated by chronic consumption of insufficiently processed cassava. The detoxification product of cyanide, thiocyanate, is a similar size to the iodine molecule and interferes with iodine uptake by the thyroid, effectively increasing the dietary requirement for iodine. The effect is only seen in iodine deficient population and can be reversed by iodine supplementation (Oyanedel et al., 2007).

Cyanide is present in some foods such as apple seeds, almonds, apricot kernel, orange seed, and cassava in the form of cyanogenic glycosides. Potential toxicity of cyanoglycosides arises from enzymatic degradation to produce hydrogen cyanide, resulting in acute cyanide poisoning. The enzyme responsible ( $\beta$ glucosidase) may arise from the plant material or from gut microflora. Clinical symptoms of acute cyanide poisoning include rapid respiration, drop in blood pressure, rapid pulse, headache, dizziness, vomiting, diarrhoea, mental confusion, stupor, blue discolouration of the skin due to lack of oxygen (cyanosis), twitching and convulsions (Heydel et al., 2008). Exposure to lower levels of cyanide over a long period results in increased blood cyanide levels. This can lead to weaknesses and a variety of symptoms including permanent paralysis, nervous lesions (Soto-Blanca et al., 2008), hypothyroidism and miscarriages (Soto-Blanca and Gornick, 2004).

Food processing procedures such as soaking, fermentation or drying will reduce the levels of hydrogen cyanide before consumption through the action of plant enzymes and subsequent leaching. Processes such as grating, soaking, fermentation and storage will allow time for conversion of cyanogenic glycosides to cyanide, while exposure to air or water will allow the cyanide to dissipate out of the food matrix. Soaking of cassava root resulted in a decrease in total cyanogen content of $13-52 \%$ after 24 hours, $73-75 \%$ after 48 hours and $90 \%$ after 72 hours (Agbor-Egbe and Lape Mbome, 2006; Kendirim et al., 1995).

Fermentation of cassava pulp or dough for 4-5 days results in a decrease in total cyanogens of 52-63\% (Kendirimet al., 1995; Obilie et al., 2004). Storage of garri, a traditional African cassava meal product, for four weeks resulted in a decreasing total cyanogen content of 50-64\% (Onabolu et al., 2002). Boiling of cassava leaves in water with added palm oil resulted in a decrease in cyanogen levels of 96 to $99 \%$ (Ngudi et al., 2003). Cooking of various cassava products (baton de manioc, fufu) resulted in reduction of the total cyanogen content of 32-55\% (Agbor-Egbe and Lape Mbome, 2006). Steaming of another cassava product (akyeke) resulted in a $74-80 \%$ reduction in total cyanogen levels (Obilie et al., 2004).

'Gasification', a process whereby fermented and dried cassava mash is simultaneously cooked and dried in a shallow wok, resulted in a 90-93\% reduction in total cyanogen content (Agbor-Egbe and Lape Mbome, 2006). Optimal cooking conditions for reduction of cyanogen levels in bamboo shoots (98$102^{\circ} \mathrm{C}$ for $148-180$ minutes) resulted in a $97 \%$ reduction in cyanogens (Ferreira et al., 1995). Overall, traditional African processes typically decrease the cyanogen content of cassava by 97$>99 \%$.

Bentonite has been reported to cause reduction in serum urea level. This is confirmed by the current study which showed significant $(\mathrm{P}>0.05)$ reduction of the serum urea level for each week of the experiment. Increasing the concentration of the bentonite administered also led to increased reduction of the serum urea level. This was also observed by Thieu et al (2008)

A significant finding in the study is the obvious reduction of the serum urea level with time as shown by the results of each week. Administration of bentonite not only cut down the serum urea level below what could have been caused by the cyanide administered but led also to a level lower than that observed in the control. 
As also observed, the reduction of plasma urea caused by the administration of bentonite is proportional to the amount of bentonite administered. Conclusion: The result of the present study indicates that cyanide exposure caused a significant increase in the plasma urea level and bentonite administration was effective in mitigating the resultant alteration. This suggests that bentonite might have some preventive and therapeutic effects on cyanide poisoning.

\section{REFERENCES}

Agbor-Egbe, T; Lape Mbome, I (2006). The effects of processing techniques in reducing cyanogen levels during the production of some Cameroonian cassava foods. J. of Food Comp. and Analysis; 19: 354-363.

Agency for Toxic Substances and Disease Registry (1997). Toxicological Profile for Cyanide. Division of Toxicology, U.S. Department of Health and Human Services. Public Health Service http://www.atsdr.cdc.gov/toxprofiles/tp8.html

Alonso, JR; Cardellach, F; López, S; Casademont, J; Miró, O (2003). Carbon monoxide specifically inhibits cytochrome c oxidase of human mitochondrial respiratory chain. Pharmacol. Toxicol. 93 (3): 142-6.

Bernan (2008). Medical Management of Chemical Casualties Handbook (4 ed.). Government Printing Off. ISBN 0-16-081320-4. 41

Bender, DA; Bender, AE (1997). Benders' dictionary of nutrition and food technology (7 ed.). Woodhead Publishing. p. 459. ISBN 1-85573475-3. 459

Biller, J (2007). Interface of neurology and internal medicine (illustrated ed.). Lippincott Williams \& Wilkins. ISBN 0-7817-7906-5. 939

Chikezie, PC; Ojiako, OA (2013). Cyanide and aflatoxin loads of processed cassava (Manihot esculenta) tubers (Garri) in Njaba, Imo state, Nigeria. Toxicol. Int. 20:261-7.

Cipollone, R; Ascenzi, P; Tomao, P; Imperi, F; Visca, $P$ (2008). Enzymatic detoxification of cyanide: clues from Pseudomonas aeruginosa Rhodanese. J. Mol. Microbiol. Biotechnol. 15 (2): 199-211.

Craig, N (2012). Bentonite clay to remove toxic heavy metals, clear diaper rashes, stop stinky feet and more. Accessed at: http://www.naturalnews.com/036972_bentonite clay_heavy_metals_detox.html
Ferreira, VLP; Yotsuyangi, K; Carvalho, CRL (1995). Elimination of cyanogenic compounds from bamboo shoots Dendrocalamus giganteus Munro. Trop. Sci. 35: 342-346.

Gitipour, S; Bowers, MT; Bodocsi A (1997). The Use of Modified Bentonite for Removal of Aromatic Organics from Contaminated Soil. J. of Col. and Inter. Sci. 196(2):191-198.

Greenwood, NN; Earnshaw, A (1997). Chemistry of the Elements (2nd Edn.), Oxford: ButterworthHeinemann. ISBN 0-7506-3365-4

Günister, E; Isci, S; Oztekin, N; Erim, FB; Ece,OI; Gungor, N (2006). Effect of cationic surfactant adsorption on the rheological and surface properties of bentonite dispersions. J. of Col. and Inter. Sci. 303(1):137-41.

Haque, MR; Bradbury, JH (2002). Total cyanide determination of plants and foods using the picrate and acid hydrolysis methods. Food Chem. 77(1): 107-114.

Heydel, S; Remenih, C; Williams, L (2008). Broadspectrum in vitro antibacterial activities of clay minerals against antibiotic-susceptible and antibiotic-resistant bacterial pathogens. The J.of antimicrob. Chemo. 61 (2): 353-361.

Hosterman, JW; Patterson SH (1992). Bentonite and Fuller's earth resources of the United States. U.S. Geological Survey Professional Paper. United States Government Printing Office, Washington D.C., USA. 1522.1

Jones, DA (1998). Why are so many food plants cyanogenic? Phytochem. 47 (2): 155-162.

Kamalu, CIO; Oghome, PA (2012) Study of starch and cyanide contents of Etche manufactured Garri. Emerg. Tre.in Eng App. sci; 3: 589-593.

Kendirim, OC; Chukwu, OA; Achinewhu, SC (1995). Effect of traditional processing of cassava on the cyanide content of garri and cassava flour. Plant Foods for Hum. Nut. 48(4): 335-339.

Klein, C; Barbara D (2007). Manual of Mineral Science. 23rd Ed. New York: John Wiley. ISBN 978-0471721574

Manzano, H ; de Sousa, AB ; Soto-Blanco, B (2007). Effects of long-term cyanide ingestion by pigs. Vet. Res. Comm. 31 (1): 93-104.

McNaught, AD; Wilkinson, A (1997). IUPAC: Compendium of Chemical Terminology, 2nd ed. 
(the "Gold Book"). Blackwell Scientific Publications.

Ngudi, DD; Kuo, YH; Lambein, F (2003). Cassava cyanogens and free amino acids in raw and cooked leaves. Food and Chem. Toxicol. 41: 1193-1197.

Obilie, EM; Tano-Debrah, K; Amoa-Awua, WK (2004). Souring and breakdown of cyanogenic glucosides during the processing of cassava into akyeke. Inter. J. of Food Micro bio. 93: 115-121.

Onabolu, AO; Oluwale, OS; Bokanga, M (2002). Loss of residual cyanogens in a cassava food during short-term storage. Inter. J. of Food Sci. and Nut. 53(4): 343-349.

Oyanedel-Craver, VA; Fuller, M; Smith, JA (2007). Simultaneous sorption of benzene and heavy metals onto two organoclays. J. of Col. and Inter. Sci. 309(2):485-92.

Ronald, E., (1932). Handbook of chemical risk assessment. Health hazards to humans, plants and animals. CRC Press, LLC 2000, N.W. Florida 33431. 944.

Sakam, IW; Harrington, H (1963). Amino acid metabolism. Ann. Rev. of Biochem. 32 (1): 35598.

Schulz, HD; Hadeler, A; Deutsche F (2003). Geochemical processes in soil and groundwater: measurement-modelling-upscaling. WileyVCH. ISBN 3-527-27766-8. 67

Shaffer, PR; Herbert, S Z; Raymond, P (2001). Rocks, Gems and Minerals. Rev. ed. New York: St. Martin's Press. ISBN 1582381321.
Shragg, TA; Albertson, TE; Fisher Jr, CJ (1982), Cyanide poisoning after bitter almond ingestion west. J. of Med. 136(1): 65-69.

Soto-Blanco, B ; Stegelmeier, BL ; Pfister, JA (2008). Comparative effects of prolonged administration of cyanide, thiocyanate and chokecherry (Prunus virginiana) to goats. J. of App. Toxicol. 28 (3): 356-63.

Soto-Blanco, B; Gorniak, SL (2004). Prenatal toxicity of cyanide in goats-a model for teratological studies in ruminants. Theriogen. 62 (6): 101226.

Sousa, AB, Soto-Blanco, B; Guerra, JL; Kimura, ET; Gorniak, SL (2002). Does prolonged oral exposure to cyanide promote hepatotoxicity and nephrotoxicity? Toxicol. 174 (2): 87-95.

Thieu, NQ; Ogie, B; Pettersson, H (2008). Efficacy of bentonite clay in ameliorating aflatoxicosis in piglets fed aflatoxin contaminated diets. Trop. Ani. Hea; Prod 40(8):649-56.

Tietz, NW (1995). Clinical guide to laboratory tests. $3^{\text {rd }}$ edition. W.B. Saunders Co. Philadelphia 874.

Vetter, J (2000). Plant Cyanogenic Glycosides. Toxicol. 38 (1): 11-36.

Young, DS (1995). Effects of drugs on clinical laboratory tests. $4^{\text {th }}$ edition. AACC press. 34

Zaitan, H ; Bianchi, D ; Achak, O ; Charik, T (2008). A comparative study of the adsorption and desorption of o-xylene onto bentonite clay and alumina. J. of Haz. Mat. 153(1-2):852-9. 